\title{
Erratum to: Le régime méditerranéen : aliments vedettes ou style alimentaire? Introduction
}

\author{
J. M. Lecerf \\ (C) Lavoisier SAS 2015
}

(C) Lavoisier SAS 2015

Erratum to: Phytothérapie DOI 10.1007/s10298-015-0945-z

Une erreur est intervenue concernant la bibliographie de cet article : nous insérons ci-dessous les références manquantes à cet article.

\section{Références}

19. Knoops KTB, de Groot LCPGM, Kromhout D, et al. (2004) Mediterranean diet, lifestyle factors, and 10-year mortality in elderly european men and women: the hale project. JAMA 292:1433-9

20. Mitrou PN, Kipnis V, Thiébaut ACM, et al. (2007) Mediterranean dietary pattern and prediction of all-cause mortality in a us population: results from the nih-aarp diet and health study. Arch Intern Med 167:2461-8

21. Menotti A, Alberti-Fidanza A, Fidanza F (2012) The association of the mediterranean adequacy index with fatal coronary events in an italian middle-aged male population followed for 40 years. Nutr Metab Cardiovasc Dis 22:369-75

22. Lopez-Garcia E, Rodriguez-Artalejo F, Li TY, et al. (2014) The mediterranean-style dietary pattern and mortality among men and women with cardiovascular disease. Am J Clin Nutr 99:172-80

23. Estruch R, Ros E, Salas-Salvadó J, et al. (2013) Primary prevention of cardiovascular disease with a mediterranean diet. N Engl J Med 368:1279-90

24. Pitsavos C, Panagiotakos DB, Tzima N, et al. (2005) Adherence to the mediterranean diet is associated with total antioxidant capacity in healthy adults: the attica study. Am J Clin Nutr 82:694-9

25. Dai J, Jones DP, Goldberg J, et al (2008) Association between adherence to the mediterranean diet and oxidative stress. Am J Clin Nutr 88:1364-70

26. Salas-Salvadó J, Garcia-Arellano A, Estruch R, et al. (2008)Components of the mediterranean-type food pattern and serum inflammatory markers among patients at high risk for cardiovascular disease. Eur J Clin Nutr 62:651-9

27. Esposito K, Marfella R, Ciotola M, et al. (2004) Effect of a mediterranean-style diet on endothelial dysfunction and markers of vascular inflammation in the metabolic syndrome: a randomized trial. JAMA 292:1440-6

28. Marin C, Ramirez R, Delgado-Lista J, et al. (2011) Mediterranean diet reduces endothelial damage and improves the regenerative capacity of endothelium. Am J Clin Nutr 93:267-74

29. Schwingshackl L, Hoffmann G (2014) Mediterranean dietary pattern, inflammation and endothelial function: a systematic review and meta-analysis of intervention trials. Nutr Metab Cardiovasc Dis 24:929-39

30. Ambring A, Johansson M, Axelsen M, et al. (2006) Mediterranean-inspired diet lowers the ratio of serum phospholipid n-6 to n-3 fatty acids, the number of leukocytes and platelets, and vascular endothelial growth factor in healthy subjects. Am J Clin Nutr 83:575-81

31. García-Calzón S, Gea A, Razquin C, et al. (2014) Longitudinal association of telomere length and obesity indices in an intervention study with a mediterranean diet: the predimed-navarra trial. Int J Obes (Lond) 38:177-82

32. Mezzano D, Leighton F, Martínez C, et al. (2001) Complementary effects of mediterranean diet and moderate red wine intake on haemostatic cardiovascular risk factors. Eur J Clin Nutr 55:444-51

33. Lapointe A, Goulet J, Couillard C, et al. (2005) A nutritional intervention promoting the mediterranean food pattern is associated with a decrease in circulating oxidized ldl particles in healthy women from the québec city metropolitan area. J Nutr 135:410-5

34. Goulet J, Lapointe A, Lamarche B, et al (2007) Effect of a nutritional intervention promoting the mediterranean food pattern on anthropometric profile in healthy women from the québec city metropolitan area. Eur J Clin Nutr 61:1293-1300

35. Woo J, Woo KS, Leung SS, et al. (2001) The mediterranean score of dietary habits in chinese populations in four different geographical areas. Eur J Clin Nutr 55:215-20

J. M. Lecerf $(\bowtie)$

Service de Nutrition, Institut Pasteur de Lille, 59000 Lille

e-mail : jean-michel.lecerf@pasteur-lille.fr 